\title{
Fusarium species isolated from peat soil of Pondok Tanjung and Sungai Beriah, Perak
}

\author{
Latiffah, Z., ${ }^{*}$ Nurul Izzati, H. and Baharuddin, S. \\ School of Biological Sciences, University Sains Malaysia, 11800 Minden, Pulau Pinang, Malaysia. \\ E-mail:Lfah@usm.my
}

Received 29 June 2009; received in revised form 5 September 2009; accepted 17 September 2009

\begin{abstract}
Isolates of Fusarium from peat soil samples were recovered using three methods namely, soil dilution, direct isolation and debris isolation techniques. Based on identification using morphological characteristics, four species of Fusarium species were identified. The most common species isolated was $F$. solani $(70.4 \%)$ followed by $F$. oxysporum $(14.8 \%), F$. semitectum (11.1\%) and F. proliferatum (3.7\%).
\end{abstract}

Keywords: Fusarium, peat soil

\section{INTRODUCTION}

Peatland accumulate peat which is an organic material develops as a results of incomplete decomposition of vegetation in the ecosystem (Shier, 1985). Peat is formed by accumulation of partially decaying plant debris such as leaves, roots, branches and twigs as well as insect and animal remains in waterlogged environments which lead to anaerobic conditions, low oxygen levels and highly acidic conditions (Whitmore, 1984; Howes, 1998). These extreme conditions prevent microorganisms from rapidly decomposing the plant debris and animal remains.

Among the microorganisms, it has been suggested that fungi are the main decomposer in many peatland ecosystems and therefore assume a more dominant role than bacteria (Latter et al., 1967; Williams and Crawford, 1983). As a decomposer, fungi have an extensive hyphal network with faster growth rate and the ability to translocate nutrients through the hyphal network to vast areas in the peatland ecosystem (Thormann, 2006).

Diverse assemblages of fungi have been recovered from peatland soils worldwide such as anamorphic ascomycete, teleomorphic ascomycete, Zygomycota and Basidiomycota (Thormann, 2006). These groups of fungi play an important role in carbon cycle and interact with plants through exchange of organic and inorganic compounds (Kamal and Varma, 2008).

From compilation of Thormann and Rice (2007) on fungi from peatlands, the genus Fusarium was one of the fungal genera isolated from different types of peatland soils. However, information on species of Fusarium from tropical peatland is lacking. Therefore, this preliminary study was conducted to determine the occurrence of species of Fusarium in peat soils from peatswamp area in Pondok Tanjung and Sungai Beriah, Perak.

\section{MATERIALS}

Soil sample

A total of five soil samples were collected from peatland area at Pondok Tanjung and Sungai Beriah, Perak. The soil samples were taken from a depth of about $1-15 \mathrm{~cm}$, stored in paper bag, and brought to the lab for drying process. The soil samples were air-dried for $48 \mathrm{~h}$ at $27 \pm$ $1{ }^{\circ} \mathrm{C}$. After drying, the soils were grinded to fine powder and sieved through a $0.05 \mathrm{~mm}$ sieve to remove plant debris and small stones. The grinded soils and plant debris were stored separately and kept in $4^{\circ} \mathrm{C}$ to be used for isolation of Fusarium isolates and soil analysis.

\section{Isolation and identification of Fusarium isolates}

Three isolation methods namely, soil dilution plate, debris isolation and direct isolation methods were used to recover isolates of Fusarium from the peat soil samples. The three isolation methods were based on the method described in The Fusarium Laboratory Manual by Leslie and Summerell (2006) for isolation of Fusarium from soils.

Isolates of Fusarium successfully isolated were identified using primary and secondary morphological characteristics according to the description and classification in The Fusarium Laboratory Manual (Leslie and Summerell, 2006). The media used for isolation and identification were also adapted from the manual.

\section{Soil analysis}

The peat soil samples were also analysed for the texture, $\mathrm{pH}$ and moisture. Soil texture was determined using feel method (Brady and Weil, 1999) and soil texture was classified based on Biondo and Lee (1997). 
Soil $\mathrm{pH}$ was measured by weighing $20 \mathrm{~g}$ of the soil and put in a $100 \mathrm{~mL}$ beaker. A $50 \mathrm{~mL}$ of distilled water were added and mixed well. The mixture was incubated for $24 \mathrm{~h}$ and the $\mathrm{pH}$ was recorded using a $\mathrm{pH}$ meter (Jenway).

The percentage of moisture was calculated by weighing $10 \mathrm{~g}$ of the soils in a Petri dish and incubated at $105^{\circ} \mathrm{C}$ for $24 \mathrm{~h}$. Then, the soils were weighted again. The percentage of moisture was calculated based on the following formula:

(weight of petri dish + soil before incubation) $\mathrm{g}-$ (weight of petri dish + soil after incubation) $\mathrm{g}$

soil moisture $(\%)=\frac{\text { (Weight of soil sample) } \mathrm{g}}{\text { (Weil }}$

\section{RESULTS}

A total of 27 isolates of Fusarium were obtained from five peat soil samples. Based on morphological characteristics, four species of Fusarium were identified (Table 1). The most common species isolated was $F$. solani $(70.4 \%)$ followed by F. oxysporum (14.8\%), F. semitectum (11.1\%) and $F$. proliferatum (3.7\%). The Fusarium species successfully recovered, the soil texture, $\mathrm{pH}$ and moisture are shown in Table 2. The peat soil samples had loamy texture with different categories namely, silty clay loam, sandy clay loam and clay loam. The isolates of Fusarium were recovered from acidic environment with $\mathrm{pH}$ ranging from $2.95-3.52$ and the moisture content of $0.58 \%-1.51 \%$

From the three isolation methods, debris isolation method had the most isolates recovered i.e. 13 isolates followed by direct isolation and soil dilution methods with 11 and three isolates, respectively (Table 3 ).

\section{DISCUSSION}

The four species of Fusarium recovered from the peat soil samples are common species found in the soils world wide. The isolates were obtained in soils with acidic conditions which are the $\mathrm{pH}$ range of peat soils. Lower moisture content could be due to the dried and warm weather during sampling. Moreover, peatland areas are subjected to periods of varying water levels.

Species of Fusarium in peat soils are probably saprobes which involved in decomposition of organic matter. Deacon (1997) grouped the genus Fusarium in group 3 behavioral grouping of decomposer fungi which degrade simple polymer. Although the information on the occurrence of Fusarium in tropical peatland soils is lacking, species of Fusarium is one of the dominant anamorphic ascomycetes recovered from boreal peatlands (Thormann, 2006), $F$. avenaceam and $F$. culmorum have been recovered from bog and fen peatland soils (Dickinson and Dooley, 1969).

Fusarium solani was the most common species recovered from the peat soil samples which are not surprising as $F$. solani is one of the most common species inhabit different types of soil and has been isolated from numerous soils in sub-tropical, semi-arid and grassland soils (Burgess and Summerell, 1992), cultivated soils (Lim and Chew, 1972; Latiffah et al., 2007), forested area (Latiffah et al., 2009) and from sandy soils (Sanquis and Borba, 1997).

Similar with F. solani, F. oxysporum was also common

Table 1: Morphological characteristics of Fusarium species isolated from peat soil

\begin{tabular}{|c|c|c|c|c|}
\hline \multirow{2}{*}{ Characteristic } & \multicolumn{4}{|c|}{ Fusarium species } \\
\hline & F. solani & F. oxysporum & F. semitectum & F. proliferatum \\
\hline Microconidia & $\begin{array}{l}\text { Abundant in aerial } \\
\text { mycelial, reniform and } \\
\text { ellipsoid with1-2 septa, }\end{array}$ & $\begin{array}{l}\text { Abundant in aerial } \\
\text { mycelial, oval to } \\
\text { reniform with } 0 \text { septa, }\end{array}$ & $\begin{array}{l}\text { Scarce in aerial } \\
\text { mycelium and rabbit } \\
\text { ear appearance (in } \\
\text { situ), pyriform to } \\
\text { obovate with } 1 \text { septa } \\
\text { mesoconidia fusoid } \\
\text { with } 3-5 \text { septa }\end{array}$ & $\begin{array}{l}\text { Microconidia in chain } \\
\text { (in situ), club shaped } \\
\text { and } 0 \text { septa. }\end{array}$ \\
\hline Macroconidia & $\begin{array}{l}\text { Abundant in } \\
\text { sporodochia, stout, } \\
\text { wide, straight and stout } \\
\text { with 4-7 septa, } \\
\text { rounded basal cell, } \\
\text { blunt and rounded } \\
\text { apical cell }\end{array}$ & $\begin{array}{l}\text { Abundant in } \\
\text { sporodochia, straight } \\
\text { to slightly curved, with } \\
3 \text { septa, foot shaped } \\
\text { basal cell, slightly hook } \\
\text { apical cell }\end{array}$ & $\begin{array}{l}\text { Slender and slightly } \\
\text { curved with } 3-5 \text { septa, } \\
\text { foot shaped basal cell, } \\
\text { curved apical cell }\end{array}$ & $\begin{array}{l}\text { Slender and relatively } \\
\text { straight with } 3-5 \text { septa, } \\
\text { not well developed } \\
\text { basal cell, curved } \\
\text { apical cell }\end{array}$ \\
\hline Conidiophore & Long monophialides & short monophialides & $\begin{array}{l}\text { Monophialides and } \\
\text { polyphialides }\end{array}$ & $\begin{array}{l}\text { Monophialides and } \\
\text { polyphialides }\end{array}$ \\
\hline Chlamydospore & $\begin{array}{l}\text { Present - in pairs and } \\
\text { singly }\end{array}$ & $\begin{array}{l}\text { Present - singly and in } \\
\text { pairs }\end{array}$ & $\begin{array}{l}\text { Present - singly and in } \\
\text { pairs }\end{array}$ & Absent \\
\hline Pigmentation & $\begin{array}{l}\text { Cream, blue, green- } \\
\text { blue }\end{array}$ & $\begin{array}{l}\text { Pale violet to dark } \\
\text { violet }\end{array}$ & $\begin{array}{l}\text { Beige, brown, } \\
\text { yellowish }\end{array}$ & Purple \\
\hline Growth rate & $3.0-3.8 \mathrm{~cm}$ & $3.4-4.0 \mathrm{~cm}$ & $3.5-4.6 \mathrm{~cm}$ & $3.4-4.0 \mathrm{~cm}$ \\
\hline
\end{tabular}


Table 2: Texture, $\mathrm{pH}$ value, moisture and Fusarium species isolated from peat soil samples

\begin{tabular}{|c|c|c|c|c|}
\hline Soil sample & Texture & $\mathrm{pH}$ & $\%$ moisture & Fusarium species \\
\hline $\begin{array}{l}\text { Pondok Tanjung } \\
\text { (forested area) }\end{array}$ & Sandy clay loam & 3.52 & $1.36 \%$ & $\begin{array}{l}\text { F. semitectum } \\
\text { F. solani } \\
\text { F. oxysporum }\end{array}$ \\
\hline Sg. Beriah Kanan 1 & Clay loam & 2.95 & $1.00 \%$ & $\begin{array}{l}\text { F. oxysporum } \\
\text { F. solani }\end{array}$ \\
\hline Sg. Beriah Kanan 2 & Clay loam & 2.98 & $1.51 \%$ & $\begin{array}{l}\text { F. oxysporum } \\
\text { F. solani }\end{array}$ \\
\hline Sg. Beriah Kiri 1 & Silty clay loam & 2.98 & $0.70 \%$ & $\begin{array}{l}\text { F. semitectum } \\
\text { F. solani } \\
\text { F. solani }\end{array}$ \\
\hline Sg. Beriah Kiri 2 & Silty clay loam & 3.41 & $0.58 \%$ & $\begin{array}{l}\text { F. oxysporum } \\
\text { F. proliferatum }\end{array}$ \\
\hline
\end{tabular}

Table 3: Number of Fusarium isolates obtained based on soil dilution, direct isolation and debris isolation techniques

\begin{tabular}{lcl}
\hline $\begin{array}{c}\text { Isolation } \\
\text { technique }\end{array}$ & $\begin{array}{c}\text { Number of } \\
\text { isolates }\end{array}$ & Fusarium species \\
\hline Soil dilution & 3 & $\begin{array}{l}\text { F. solani } \\
\text { F. oxysporum } \\
\text { F. solani }\end{array}$ \\
Direct isolation & 11 & $\begin{array}{l}\text { F. oxysporum } \\
\text { F.semitectum } \\
\text { F. proliferatum }\end{array}$ \\
Debris plating & 13 & $\begin{array}{l}\text { F. solani } \\
\text { F. oxysporum } \\
\text { F.semitectum }\end{array}$ \\
\hline Total & 27 & \\
\hline
\end{tabular}

soil fungi recovered from various types of soil from agricultural soils (Onyike and Nelson, 1993; Skorgaard et al., 2000; Latiffah et al., 2007) to non-agricultural soils (Joffe and Palti, 1977; Sarquis and Borba, 1977 and balmas, 1999). From peatland soils, F. oxysporum was one of the soil fungi isolated from fen peatland (Stenton, 1953) and $F$. oxysporum has also been isolated from rhizosphere and roots of Spartina alterniflora in Dongtan wetland in China (Luo et al., 2007).

Fusarium semitectum is widely distributed as saprophyte in soils and most probably exists as soil inhabitants (Burgess et al., 1988, Leslie et al., 1990). Fusarium semitectum was also one of the species of Fusarium, recovered in Dongtan wetland, China (Luo et al., 2007).

$F$. proliferatum also occur in wide variety of agricultural soils and has been isolated sporadically in nonagricultural soils in Australia (Burgess and Summerell, 1992; Summerell et al., 1993) and found to be abundant in rhizosphere of Livistona mariae palms (Gott et al., 1994).

In conclusion, four species of Fusarium were isolated from peat soil samples from Pondok Tanjung and Sungai Beriah, Perak. The species were F. solani, F. oxysporum, $F$. semitectum and F. proliferatum.

\section{REFERENCES}

Balmas, V., Corazza, L. and Magnotta, A. (1999). Occurrence of Fusarium species in uncultivated soils in Italy. Micologia Italiana 28, 5-8.

Biondo, R. J. and Lee, J. S. (1997). Introduction to Plant and Soil Science Technology. Interstate Publishers Inc.

Brady, N. C. and Weil, R. R. (1999). The Nature and properties of soils, $12^{\text {th }}$ edition. Prentice Hall Inc.

Burgess, L. W. and Sumerell, B. A. (1992). Mycogeography of Fusarium: Survey of Fusarium species from sub-tropical and semi-arid grassland soils from Queensland, Australia. Mycological Research 96, 780-784.

Burgess, L. W., Nelson, P. E., Toussoun, T. A. and Forbes, G. A. (1988). Distribution of Fusarium species in sections Roseum, Arthrosporiella, Gibbosum and Discolor recovered from grassland, pasture and pine nursery soils in eastern Australia. Mycologia 80, 815-824.

Burgess, L. W. and Summerell, B. A. (1992). Mycogeography of Fusarium: survey of Fusarium species in sub-tropical and semi-arid grassland soils from Queensland, Australia. Mycological Research 96, 780-784.

Deacon, J. W. (1997). Modern Mycology, $3^{\text {rd }}$ edition. Blackwell, Boston.

Dickinson, C. M. and Dooley, M. J. (1969). Fungi associated with Irish peat bogs. Proceedings of the Royal Irish Academy, Section B. 68, 109-136.

Gott., K. P., Burgess, L. W., Balmas, V. and Duff, J. (1994). Mycogeography of Fusarium : Fusarium species in soils from Palm Valley, Central Australia. Australasian Plant Pathology 23, 112-117

Howes, J. (1998). Peatswamp forests of Sarawak. In: The Encyclopedia of Malaysia. The Environment. Sani, S. (ed.). pp. 54-55.

Joffe, A.Z. and Palti, J. (1977). Species of Fusarium found in uncultivated desert-type soils in Israel. Phytoparasitica 5, 119-121. 
Latiffah, Z., Mohd. Zariman, M. and Baharuddin, S. (2007). Diversity of Fusarium species in cultivated soils in Penang. Malaysian Journal of Microbiology 3, 27-30.

Latiffah, Z., Padzilah, M. I., Baharuddin, S. and Maziah, Z. (2009). Fusarium species in forest soil of Bird Valley. Malaysian Journal of Microbiology 5, 132-133.

Latter, P. M., Cragg, J. B. and Heal, O. W. (1967). Comparative studies on the microbiology of four moorland soils in the northern soils in the northern Pennines. Journal of Ecology 55, 445-464.

Leslie, J. F. and Summerell, B. A. (2006). The Fusarium Laboratory Manual, $1^{\text {st }}$ edition. Blackwell Publishing, Ames, lowa, USA.

Leslie., J. F., Pearson, C. A. S., Nelsom, P. E. and Toussoun, T. A. (1990). Fusarium species from corn, sorghum and soybean fields in the central and eastern United States. Phytopathology 80, 343-350.

Lim, G. and Chew, C. H. (1970). Fusarium in Singapore Soils. Plant and Soil 33, 673-677.

Luo, J-L., Bao, K., Nie, M., Zhang, W-Q., Xiao, M. and Li, B. (2007). Cladistic and phonetic analyses of relationships among Fusarium species in Dongtan wetland by morphology and isozymes. Biochemical and Systematics Ecology 37, 410-420.

Onyike, N. B. N. and Nelson, P. E. (1993). The distribution of Fusarium species in soils planted to millet and sorghum in Lesotho, Nigeria and Zimbabwe. Mycopathologia 121, 105-114.

Sarquis, M. I. M. and Borba, C. M. (1997). Fusarium species in sandy soils from Ipanema Beach, Rio de Janeiro, Brazil. Journal of Basic Microbiology 37, 425-439.

Shier, C. W. (1985). Tropical peat resources. An overview. In: Proceedings of Symposium Tropical Peat Resources, Prospects and Potential. Kingston, Jamaica. 25 February - 1 March 1985. Helsinki University Press. pp. 29-46.

Skovgaard, K., Bødker, K. and Rosendahl, S. (2002). Population structure and pathogenicity of members of the Fusarium oxysporum complex isolated from soil and root necrosis of pea (Pisum sativum $\mathrm{L}$ ). FEMS Microbiology Ecology 42, 367-374.

Stenton, H. (1953). The soil fungi of Wicken fen. Transactions of the British Mycological Society 36, 304-314.

Summerell, B. A., Rugg, C. A. and Burgess, L. W. (1993). Mycogeography of Fusarium: Survey of Fusarium species associated with forest and woodland communities in north Queensland, Australia. Mycological Research 97, 1015-1019.

Thormann, M. N. (2006). The role of fungi in boreal peatlands. In: Boreal Peatland Ecosystems. Ecological Studies vol. 188. R. Kelman Wieder and H.V. Dale (eds.). Springer Berlin Heidelberg.

Thormann, M. N. and Rice, A. V. (2007). Fungi from peatlands. Fungal Diversity 24, 241-299.

Whitmore, T. C. (1984). Tropical rainforests of the Far East. Clarendon, Oxford.
Williams, R. T. and Crawford, R. L. (1983). Microbial diversity of Minnessota peatlands. Microbial Ecology 9, 201-214. 